UDC 342.9

DOI https://doi.org/10.32837/pyuv.v2i4(29).452

\author{
R.M.Opatsky \\ orcid.org/0000-0002-8658-8153 \\ Doctor of Law, \\ Associate Professor of the Department of Administrative Law, Process and Administrative Activity \\ Dnipropetrousk State University of Internal Affairs
}

\title{
BULLING AND ITS NEIGHBORHOOD: A COMPARATIVE ASPECT
}

Introduction. The most important and priority task of every democratic state is to protect the life and health of the individual and the citizen. The Constitution of Ukraine proclaims human life and health, its honor and dignity, inviolability and security as the highest social value (Article 3), stating that "no one shall be subjected to torture, cruel, inhuman or degrading, treatment or punishment "(p. 28) [1]. The prohibition of torture meets the requirements of international legal instruments, on the basis of which every state, including Ukraine, regards acts of torture as crimes [2].

Formulation of the problem. The problem of violence in the human environment, and especially in adolescents, testifies to the need for careful study and development of preventive measures to address it, since children, on the one hand, are the most vulnerable, most vulnerable and almost completely dependent on society. On the other hand, there is a problem of qualification of unlawful acts, their differentiation from joint socially dangerous acts, and therefore the type and severity of punishment of the guilty person.

Analysis of the publications that started solving this problem. Foreign scholars such as I. Berdyshev, I. Kohn, X. Leimann, D. Lane, K. Lorenz, D. Olveus and others have thoroughly covered the problem of student violence. In domestic jurisprudence, the problem of bullying (harassment) was developed by E. Gribanov, R. Ivpchenko, B. Logvinenko, S. I. Ignatov, and I. Kravchenko, however.

Therefore, the purpose of the article is to attempt to differentiate the billing from related violations, and to outline the specific features that will enable such actions to be properly qualified.

Presenting main material. Nowadays, in Ukraine, as in the whole world, an extremely acute and widespread problem is the aggressive manifestation in the interpersonal relations of student youth. Currently, the relevance of the study of this phenomenon is due to the fact that, first, the number of fixed cases of this phenomenon increases. At the end of November 2017, the Ukrainian Institute for Extremism Studies found that 8 out of 10 children are experiencing bullying in Ukraine [3]. Also, according to the Human Rights Information Center, as of July 2017, $67 \%$ of children in Ukraine between the ages of 11 and 17 have been experiencing a bullying problem over the last three months. $24 \%$ of children were harassed, and $48 \%$ did not even tell anyone about these cases [4]. According to the World Health Organization (WHO), Ukraine ranks fourth among European countries in terms of adolescent aggression. In the first place - Russia, in the second Albania, in the third - Belarus [4].

Secondly, the situation of bullying leads not only to social but also to pedagogical(school maladaptation and failure), psychological (psychological disorders, decreased self-esteem, impaired socialization) and medical (traumatizing) consequences.

Third, the problem was investigated mainly by Western scholars. It is not in Ukraine that systematic nationwide studies of this phenomenon (solitary) are conducted, and therefore the methods of its prevention and correction are not offered sufficiently.

Fourth, to date, there is no single broad definition of this phenomenon, but different terms and related concepts are used, in my opinion, on which research should be focused, in order to bring clarity to the very concept of "billing" and its varieties, as well as to improve the apparatus of youth protection against harassment and humiliation.

It should be noted that not every violence and every unwanted behavior of young people can be considered as bullying. The severity and duration of this process are directly related to the victim's response to verbal, physical, or psychological aggression. Therefore, it is necessary to outline the basic definitions and characteristics of the concept of bullying related concepts in order to be able to regard certain acts as unlawful and criminal and to consider them as requiring the intervention of adults or other authorities.

As already noted, one of the most common problems in the child's environment today is bullying, which is considered to be unwanted aggressive behavior by school-age children, leading to the bullying of another child or a group of children for the purpose of humiliation, intimidation and demonstration of force.

British researchers D. Lane and E. Miller defines bullying as a long-term process of conscious abuse, whether physical or mental, by an individual or group against another individual who is unable 
to protect himself / herself in this situation [5]. D. Olveus means bullying by intentional, systematically repeated and aggressive behavior, including inequality of social power or physical strength. E. Roland defines bullying as a social system that includes the persecutor, the victim, and outside observers [6, p. 50].

In general, the term "bullying" comes from the English verb to bully, which according to the Cambridge Dictionary has the following meaning: "to offend or intimidate someone who is less or less influential than you, often forcing a person to do undesirable actions", as well as English the noun a bully is a bully, a brawler [7].

Bulling is, of course, violence of a deliberate nature and manifested, as a rule, in prolonged, repeated physical and / or mental actions by a person or group of persons with certain advantages (physical, administrative, psychological, etc.), committed for a specific, specific purpose (to intimidate, to make a confession of something, to punish for committing an act, etc.).

Given the above, it is possible to deduce the main features of bullying (bullying), such as: the presence of the subject (buller) is usually a person under the age of majority; the presence of a victim; direct intent, that is, actions aimed at intentionally causing physical or psychological harm; systematic, unlawful actions must be systemic in nature and occur with some repetition; mandatory presence of witnesses (observers) and / or the ability of a certain number of individuals to witness illegal acts (this can be either a direct physical contact between the Buller and the victim, as well as an online bulletin to allow third parties to evaluate the actions) [14, p. 267].

In view of the foregoing, I propose to consider torture as a separate manifestation of juvenile bullying as a first related concept. And given the common features of such acts and the particular threat to life, health, will, honor and dignity of a person as a criminal being protected in Ukraine, certain manifestations of bullying may fall under Art. 127 of the Criminal Code of Ukraine and qualify as torture.

Another concept is mobbing, which is considered one of the varieties of billing. Interestingly, this word was first used by ethnologist K. Lorenz to describe the behavior of a group of small animals (most often birds) attacking one stronger and larger animal with small but massive impacts [8]. In general, mobbing is a form of psychological violence in the form of harassment of an employee in a team with a view to his subsequent dismissal. Such persecution is spreading very quickly in the team. In this case, victims of this phenomenon are usually individuals who stand out from other workers and who have demonstrated the mind or competence, education or creativity in their work. Sometimes management uses mobbing purposefully to get rid of unwanted employees [9].

In psychology and medicine the term "mobbing" was introduced in 1960 by the Swedish doctor P.Heinemann, who in his book Mobbing - Group Violence among Children and Adults [10] compared the behavior of children with peers with aggressive animal behavior. Later, another Swedish researcher $\mathrm{H}$. Leiman, on the basis of studying the behavior of people in the labor collective, described mobbing as "psychological terrorism", in which the hostile attitude of one or more persons to another person is systematically repeated [11].

In his 1998 book Violence at Work [12], published by the International Labor Office (ILO), mobbing was put on a par with murder, rape or robbery. Although mobbing may seem completely innocent compared to rape or other physical violence, the effect it produces on the victim, especially if it is protracted, has a devastating effect that can lead to suicide.

In essence, mobbing and bulling are similar concepts, but at the same time, bulling differs from mobbing in that it is not the whole class but the particular student or group of students who have the authority to pursue the role of the pursuer.

Another related concept, or even type of billing, is haze [13]. Hazing is an informal ritualistic rite of passage performed when joining a particular group, and to further support the hierarchy in that group. To a greater extent, hazing is characteristic of closed (paramilitary, sports, boarding, etc.) establishments. On the other hand, this concept can be considered as irrelevant relations in the collective, for example, we know "hazing".

Hazing is also found in mainstream schools and colleges, especially if they have dormitories. Beginner classmates or students of the upper classes (courses) are forced to take various actions, for example, to walk publicly undressed, to wash the floor in the toilet with a toothbrush, etc. (examplea resonant dedication to students with undress in one of the country's universities this year).

Hazing is considered to be a form of bullying, as it is also a form of aggressive behavior, which usually involves intimidation and humiliation, but it occurs precisely in the process of dedication or acceptance of a particular club, group, etc., but in any case degrades the honor and dignity of a person. .

Charassment is another English-language word that can be compared to bulling. The closest analogy to "harassment" is "sexual harassment", but the English term is broader. It includes not only actions, but also offensive remarks, indecent suggestions, and psychological harassment.

The very word appeared in the early seventeenth century in France: harasser meant "to hunt a hunting dog for game". Now the Oxford Dictionary 
defines character as "unwanted sexual suggestions or hints of obscene nature, usually addressed to a woman".

Research has shown that workplace charisma has a catastrophic effect on women, their sense of self-confidence, and their desire to continue working. Aggressive sexual harassment reduces the enthusiasm of employees, worsens their performance, sometimes leading to depression and panic.

Drawing on the analogy with billing, charassment is an aggressive manifestation, but not in young people, but in the relationship between a man and a woman at work, there are also manifestations of such influence, even in the street.

Another concept that can be compared to billing is stalking, which means intrusive attention to one person by another person or group of people. Stalking is a form of harassment carried out through intimidation and, as a rule, is the pursuit of, and the pursuit of, the victim.

The community of stalking and billing is that it carries a systematic character, and this brings great psychological trauma to the victim. And the main difference lies in the mechanism of causing this injury. That is, a stalker is a person who literally follows you, makes calls, writes messages, can even leave gifts (including a scary one, such as the heart of a killed animal), get your friends and relatives (often hinting at the sexual context of your relationship or his desires towards you).

As a result, you feel constant control and attention to yourself, the inability to manage your life (getting rid of the stalker at will is almost impossible), so at some point fear overtakes even the most courageous person.

It is also very widespread in our time developed Internet resource, such a concept as a hat, which is considered full of hatred, contempt, anger activity, human activity on the Internet. It can be directed against either a specific person, or against representatives of a particular nation, gender, a person of another appearance, followers of a particular religion or political group, representatives of show business, and even just acquaintances. Thus, virtually anyone can become the object of "network hatred".

According to data provided by SWPS, one in four people using the Internet has ever fallen victim to a hack, and $11 \%$ of internet users admit that they sometimes have to become the same hackers on the Web.

The reason for the hight can be envy, dissatisfaction with their life situation, unpleasant experience.Because of this, its victims are public figures, public figures, celebrities, and also just acquaintances who have achieved financial success, have an interesting job or a happy personal life.
Haight in such cases is the result of frustration, lack of satisfaction with one's life.

The concept of bodybuilding, as another related concept to billing, is not known to all. Bodybuilding can be characterized as a phenomenon where some people criticize others for features that are outside the conventional standards of beauty. Bodyshimers are people who are used to actively discussing someone else's appearance, thinking about what would be best for a particular person. It is worth noting that in most cases, the expression of such users is not limited to words - photo editors and other tools that make a photo subject to mockery and mockery are in progress.

According to psychologists, the inappropriate behavior of bodyshimers is related to those rules that prevail in modern society. Tearing other people in such ways, they try to devalue the person in their eyes and thus feel at least a little significant. Very often the desire to criticize the looks and figures of other people is associated with the disadvantages of their own appearance.

Therefore, given the above, it should be noted that bulling has much in common with other offenses, which are aimed at degrading honor, dignity, and sometimes physical abuse, from the individual. In our view, the phenomenon of violence and oppression by a certain criterion dates back to the early teens (which is directly bullying) and continues to exist in society in various manifestations: on the street, at work, and most often on the Internet.

At the same time, society is condescending to this shameful phenomenon (especially in the adult environment). Eradicating this phenomenon is an extremely complex task and at the same time important, the fragments require a change in the model of relationships between people at the present stage of society.

The main directions in this direction are: improvement of the legal framework, in the part of the normative fixing of responsibility not only for billing, but also for similar other types of offenses; consolidation at the legislative level of such concepts as mobbing, hazing, stalking, etc.; fixing the passage of a mandatory corrective program by abusers.

\section{References}

1. The Constitution of Ukraine of 28.06.1996. Access mode: http://zakon2.rada.gov.ua/laws/ show $/ 254 \mathrm{k} / 96$-ver.

2. The sad fact is that even in the 21st century, the use of torture has to be combated: Amnesty International press release (MA Index: POL 30/006/2003 (Public). Access Mode: http://amnesty.org.ru/node/1089.

3. Ukrainian Institute for the Study of Extremism. Stop School Terror Study. Prevention and counteraction of bulling. Access mode: http://uire.org.ua/wpcontent/ uploads/2017/11/Doslidzhennya-buling.pdf.

4. $67 \%$ of children in Ukraine were abused in the previous 2-3 months. Access mode: https://humanrights. 
org.ua/material/67_ditej_v_ukrajini_detected_ck van_u_forward_23 misjiaci.

$\overline{5}$. D.A. Lane School bullying. Access mode: http:// psifeya.ru/wpcontent/uploads/2014/02/LaneD._Schoolbaiting-bulling-article.doc Title. from the screen. The language is Russian.

6. E.I. Pogorelova, I.V.Arkova, A. C. Golubovskaya Psychological features of adolescents involved in the cyberbullying situation. North Caucasian Psychological Bulletin. 2016. № 14/2. pp. 47-53.

7. Meaning of "bully" in the English Dictionary. Access mode: https://dictionary.cambridge.org/ dictionary/english/bully?q=bullying \#translations.

8. Lorenz K. Das sogenannte Bose: Zur Naturgeschichte der Aggression. Wien: BorothaSchoeler, 1963

9. T.Yu. Bazarov Conflict management. Mobbing. Business education. 2006. June 15 (Electronic Journal). URL: https://ubo.ru/ articles /? Id = 1167 (accessed 20/02/2019) 3. Lorenz K. Das sogenannte Bose: Zur

10. A.V. Skavitin The problem of worries in the workplace. Management in Russia and abroad. 2004. №5.C. 118-126.

11. H. Leymann The content and development of mobbing at work. European Journal of Work and Organization Psychology. 1996. N 5 (2). P. 165-184.

12. 12.Violence at work. Access mode: https://www. livelib.ru/book/1000192760/about-violence-at-workduncan-chappell

13. The meaning of the word "hashing". Access mode: https: //exam.ph/wd/heizing.

14. B.O. Logvinenko, S.O. Ignatov Problematic Prospects for Administrative Responsibility for Committing Bullying Comparison. 2018. № 6. p. 266-268.

\section{Summary}

Opatsky R. M. Bulling and related concepts: a comparative aspect. - Article.

The problem of violence in the human environment, and especially in adolescents, testifies to the need for careful study and development of preventive measures to address it, since children, on the one hand, are the most vulnerable, most vulnerable and almost completely dependent on society. The author emphasized the problem of qualification of unlawful acts, their differentiation from joint socially dangerous acts, and therefore the type and severity of punishment of the guilty person. An attempt has been made to compare billing with similar offenses in its own generic object. It has been established that in modern society various forms of persecution are manifested, covering absolutely all age and social groups.

The author made an attempt to independently identify the main signs of bullying, which include: presence of the offender (Buller) - a person under 18 years of age; the presence of a victim; a direct intent, that is, a direct desire to cause physical harm / pain, or to make a moral humiliation of the victim, usually by witnesses or on the public Internet; systematic; the ability of a third party to witness (bystander) wrongdoing.
It is concluded that the manifestation of bullying underlies such offenses in the adult life of the offender. It is proposed to fix at the normative level various manifestations of psychological and physical abuse, such as: mobbing - hiring an employee in a team with the purpose of his subsequent dismissal; hazing - informal ritualistic violent rites performed when joining a particular group and to further support the hierarchy in that group; stalking - bullying, harassment, victim tracking, etc; hat - a display of hatred, contempt for human activity on the Internet; Body-shaming is a humbling criticism for features that go beyond conventional beauty standards, as well as providing for a mandatory corrective program for the abuser.

Key words: torture, mobbing, haze, stalking, bulling.

\section{Анотація}

Опацький P. М. Булінг та суміжні з ним поняття: порівняльний аспект. - Стаття.

Проблема насильства у людському середовищі, а надто у підлітковому, свідчить про необхідність ретельного вивчення й розробки профілактичних заходів, спрямованих на їі вирішення, оскільки діти, з одного боку, є найнезахищенішою, найуразливішою й майже повністю залежною частиною суспільства. Автором наголошено на наявності проблеми кваліфікації протиправних дій, їх розмежування від сумісних суспільно-небезпечних діянь, а отже, і вид та суворість покарання винної особи. Здійснено спробу провести порівняння булінгу з подібними за своїм родовим об'єктом правопорушеннями. Встановлено, що в сучасному суспільстві проявляються різні форми цькування, які охоплюють абсолютно всі вікові та соціальні групи.

Автором здійснено спробу самостійно визначити основні ознаки булінгу, до яких віднесено: наявність кривдника (буллера) - особи, яка не досягла 18-річного віку; наявність жертви; прямий умисел, тобто пряме бажання завдати фізичної шкоди / болю або здійснити моральне приниження жертви зазвичай у присутності свідків чи в мережі Інтернет із загальним доступом; системність; можливість третьої сторони бути свідком (спостерігачем) протиправних дій.

Зроблено висновок, що прояв булінгу лежить в основі подібних правопорушень у дорослому життя кривдника. Запропоновано на нормативному рівні закріпити різні прояви психологічного та фізичного збиткування, такі як: мобінг - цькування співробітника в колективі з метою його подальшого звільнення; хейзинг - неформальні ритуальні насильницькі обряди, виконувані у разі вступу в певну групу і для подальшої підтримки ієрархії в цій групі; сталкінг - залякування, переслідуванні жертви, стеження за нею тощо; хейт - прояв ненависті, презирства до активності людини в Інтернеті; бодішеймінг - принизлива критика за особливості зовнішності, що виходять за межі загальноприйнятих стандартів краси, а також передбачити проходження обов'язкової корекційної програми для кривдника.

Ключові слова: катування, мобінг, хейзинг, сталкінг, булінг (цькування). 